\title{
Diet of two sympatric insectivores bats (Chiroptera:Vespertilionidae) in the Cerrado of Central Brazil
}

\author{
Ludmilla M. S. Aguiar ${ }^{1} \&$ Yasmine Antonini ${ }^{2}$
}

1'Laboratório de Ecologia de Vertebrados, Embrapa Cerrados. Rodovia BR 020, km 18, Caixa Postal 08223,
$73301-970$ Planaltina, Distrito Federal, Brasil. E-mail: Iudmilla@cpac.embrapa.br
2 Departamento de Ciências Biológicas, Instituto de Ciências Exatas e Biológicas, Universidade Federal de Ouro Preto.
Campus Morro do Cruzeiro, Bauxita, 35400-000 Ouro Preto, Minas Gerais, Brasil. E-mail: antonini@iceb.ufop.br

ABSTRACT. We examined food habits of Vespertilionidae bats Myotis nigricans (Schinz, 1821) and Eptesicus furinalis (d'Orbigny, 1847) by fecal analysis in cerrado sensu stricto and gallery forests, within APA - Gama-Cabeça-de-Veado, Brasília, Distrito Federal, Brazil. Out of 20 fecal samples collected, seven were of Eptesicus furinalis and 13 of Myotis nigricans. The diet of $E$. furinalis included six orders of insects: Coleoptera (5/7 by items presence), Lepidoptera and Hymenoptera (3/7), Diptera, Hemiptera and Homoptera (1/7). The diet of M. nigricans included all the main orders consumed by $E$. furinalis $(6 / 13,4 / 13,4 / 13,3 / 13,1 / 13$, and $4 / 13$ respectively) and one other order: Orthoptera (1/13). Homoptera, Diptera and Orthoptera were collected only in bats captured in gallery forest. There is $80 \%$ of overlap in the diet of these two species. Predation on species of Scarabeidae, Hesperiidae, Sphingidae and Saturniidae families confirms bats potential as biological control agents of pests in agricultural ecosystems.

KEY WORDS. Biological pest control; insectivory; mammals; niche.

RESUMO. Dieta de duas espécies simpátricas de morcegos insetívoros no Cerrado do Brasil Central. Foi examinado o hábito alimentar das espécies de Vespertilionidae Myotis nigricans (Schinz, 1821) e Eptesicus furinalis (d'Orbigny, 1847) por meio de análise de amostras fecais coletadas em animais capturados em área de cerrado sensu stricto e matas de galeria, na APA - Gama-Cabeça-de-Veado, Brasília, Distrito Federal, Brasil. Um total de 20 amostras fecais foi analisado, sendo sete de E. furinalis e 13 de M. nigricans. A dieta de E. furinalis incluiu seis ordens de insetos: Coleoptera (5/7) (presença na amostra total), Lepidoptera e Hymenoptera (3/7), Diptera, Hemiptera e Homoptera (1/7). A dieta de M. nigricans incluiu todas as ordens consumidas por $E$. furinalis $(6 / 13,4 / 13,4 / 13,3$ / $13,1 / 13$, and $4 / 13$ respectively) e uma ordem a mais: Orthoptera (1/13). Homoptera, Diptera e Orthoptera só foram amostrados para morcegos capturados em mata de galeria. Há $80 \%$ de sobreposição na dieta destas duas espécies. A predação sobre espécies das famílias Scarabeidae, Hesperiidae, Sphingidae e Saturniidae confirma o potencial dos morcegos como agentes de controle biológicos de pragas em ecossistemas agrícolas.

PALAVRAS-CHAVE. Controle biológico de pestes agrícolas; insetivoria; mamíferos; nicho.

One of the most widely used organisms division is that of beneficial and adverse (or pest) organisms (BRown et al. 2001). In agriculture, pests include those that feed on plants parts, either above or below-ground, during a particular phase of their life cycle, leading to potentially important decreases in plant production (BRown et al. 2001). Insectivorous bats are major predators of nocturnal insects and have the potential to act as biological pest control agents in farmlands (LeELAPAIBUl et al. 2005).

Myotis nigricans (Schinz, 1821) and Eptesicus furinalis (d'Orbigny, 1847) are considered to be insectivorous species, feeding typically on small invertebrates (Aguirre et al. 2003). They are small bats (3-8 g) belonging to the Vespertilionidae family, and both are widely distributed over the Neotropical
Region. Myotis nigricans is found from Nayarit and Taumalipas (Mexico) to Peru, Bolivia, north Argentina, Paraguay and Brazil, and Eptesicus furinalis from north Argentina, Paraguay, Bolivia, Brazil, and the Guyanas east to Peru and north to Jalisco and Taumalipas (Mexico) (Simmons 2005). Both species are sympatric over most of their range.

Knowledge of food habits enables the identification of agricultural pests consumed by bats (WHITAKER 1995). Besides that, insectivorous bats are susceptible to the accumulation of toxins such as pesticides because of their high trophic rank and longevity (Clawson \& Clark 1989). So, knowledge of bats food habitats is also useful in identifying potential sources of toxins (ClaWson \& Clark 1989). The diets of most insectivorous 
bats probably reflect temporal, seasonal, and geographical variation in insect abundance, with some degree of flexibility in prey selection (Whitaker 1995, Whitaker et al. 1996). Publicizing such information can be a powerful conservation tool for bats (AgOsta 2002) and valuable information for agriculture production systems management.

According to KREBS (1998) resource partitioning is one way by which sympatric guild species share their resources, and sharing may be spatial, temporal or trophic. Description of resource partitioning between sympatric species (see AGUIAR $\&$ Marinho-FilHo 2004) can be used to determine the factors that allow species to coexist. The purpose of this work is thus to investigate the relations between trophic niches of these two insectivores, which occur sympatrically in the APA GamaCabeça de Veado, Brasília, Central Brazil, checking for overlap and seasonal variation in their diets, identifying and quantifying the main food items taken by these bats, and investigate their potential as pest control agents.

Together with Chaco and Caatinga, the Cerrado biome forms a broad open vegetation corridor separating the large blocks of Amazonian and Atlantic forests (Aв'Saber 1977, Prado \& Gibis 1993). The Cerrado is covered mainly by savanna-like vegetation (EITEN 1972), but evergreen forests occur as narrow belts along rivers and streams. These forests are termed gallery forests (EITEN 1990). The cerrado sensu stricto (s.s.) is the dominant physiognomy in this biome and presents trees with $3 \mathrm{~m}$ or more in height, which promote a cover of 10 to $30 \%$, not forming a continuous canopy. In few cases, trees may promote a cover of $60 \%$ (EITEN 1990). The Cerrado is responsible for $20 \%$ of the country's agriculture production and uses 78.5 million ha of land (IBGE 2007).

\section{MATERIAL AND METHODS}

The Environmental Protection Area (APA) of GamaCabeça-de-Veado encompasses the Fazenda Água Limpa (FAL) reserve, the Ecological Reserve of IBGE (RECOR) and the Botanical Garden of Brasília. It has 25000 ha, and all the reserves totalize $9000 \mathrm{ha}$; the APA is located between $15^{\circ} 52^{\prime}-15^{\circ} 59^{\prime} \mathrm{S}$ e $47^{\circ} 50^{\prime}-47^{\circ} 58^{\prime} \mathrm{W}$, with mean altitude of $1100 \mathrm{~m}$. Its vegetation is a typical cerrado s.s. and gallery forests. The climate presents two distinct seasons, the rainy (October to April) and the dry season (May to September). Annual precipitation is $1,600 \mathrm{~mm}$, and the temperature varies from 18 to $22^{\circ} \mathrm{C}$ (RECOR 2007).

The feeding habits of Myotis nigricans and Eptesicus furinalis were determined on the basis of fecal samples collected during 12 months, in cerrado s. s. and gallery forests, from April 1998 to March 1999. Monthly capture-recapture sessions were carried out utilizing ten mist nets (ATX $12 \times 2.5 \mathrm{~m}, 38$ $\mathrm{mm}$ mesh, four shelves) set in different sites to sample bats. Cotton bags were used to keep captured individuals before examination. Bat feces were placed on glassine paper envelopes for later analyses. All captured bats were measured, marked with numbered plastic rings and released. In the laboratory, each fecal sample was observed under a microscope and items were sorted, and food item remains were selected for analysis. Insect structures were compared with specimens deposited the Universidade Federal de Minas Gerais (UFMG). The importance of each prey type was analyzed based on the frequency of its occurrence in the samples (percentage of the total samples in which a certain item was found).

For the study of niche width of both species, the standardized index of diversity of Shannon-Wienner (KREBS 1998) was calculated. Standardized trophic niche widths allow for comparisons of diets with different numbers of prey categories. Diet overlap was calculated using the index of Pianka (KREBS 1998). Values may range from zero (no resource shared) to 1.0 (total overlap). To calculate the difference in the use of certain items between seasons of the year (dry or rainy season), the Cochran's Q test was used (ZAR 1996).

\section{RESULTS AND DISCUSSION}

Of the fecal samples collected, seven were of Eptesicus furinalis and 13 of Myotis nigricans (Tab. I). A total of seven insect orders were detected in the diet of both species totaling 23 items for E. furinalis and 29 for M. nigricans. The items in the diet of $E$. furinalis and M. nigricans at the study site were, by order of frequency: Coleoptera, Lepidoptera, Hymenoptera, Diptera, Orthoptera and Hemiptera.

Coleoptera items were most often found in fecal samples of both species. Coleoptera were found nine times (39\%) in $E$. furinalis samples and 11 (36.6\%) in M. nigricans samples. Beetles of coleoptera family Scarabeidae were identified. Scarabeidae are adapted to most habitats and feeding habits; adults of some species are diurnal and can be found over vegetation, while others are nocturnal and can be attracted by artificial light (TASHiro 1990). Many species in the larvae phase feed on rotten roots, but may also consume live roots, whilst most adults use fruits or leaves (RATCLIFf 1991).

The Lepidoptera families that could be identified in these samples were moths of Hesperiidae, Sphingidae and Saturniidae. Hesperiidae are generally small, mostly brown Butterflies, with short fat bodies, hooked antennae and rapid, skipping flight. Sphingidae are large to very large moths, with characteristic bullet-shaped bodies and long, blade-like wings. The antennae are relatively short, clubbed, and hooked at the apex. The legs are sturdy, armed with sharp spurs, and sometimes bear coaxal olfactory organs. And Saturniidae species are medium to very large in size. Larvae are usually very fleshy, with clumps of raised bristles. All four New World subfamilies of Saturniidae are represented in the Cerrado by 167 species belonging to 50 genera (CAMARgo \& Becker 1999).

Lepidoptera was the second most frequently item found in samples of M. nigricans, representing $23.3 \%$ of its diet. For $E$. furinalis Lepidoptera represented $17.3 \%$, the same percentage that Hymenoptera contributed to this species diet. These two orders of insects are consumed differently by the two species.

Revista Brasileira de Zoologia 25 (1): 28-31, March, 2008 
Table I. Food items found in seven Eptesicus furinalis and 13 Myotis nigricans fecal samples at the APA - Gama-Cabeça-de-Veado, Brasília, Central Brazil. (N) Number samples, (division) number of items in total sample.

\begin{tabular}{|c|c|c|c|c|c|c|c|}
\hline \multirow{2}{*}{$\begin{array}{l}\text { Species/month/habitat } \\
\text { Eptesicus furinalis }(\mathrm{N}=7)\end{array}$} & \multicolumn{7}{|c|}{ Insect orders } \\
\hline & Coleoptera & Lepidoptera & Diptera & Homoptera & Hymenoptera & Orthoptera & Hemiptera \\
\hline \multicolumn{8}{|l|}{ Gallery forest } \\
\hline October & 1 & 1 & 0 & 0 & 0 & 0 & 0 \\
\hline November & 1 & 0 & 0 & 0 & 1 & 0 & 1 \\
\hline February & 1 & 1 & 1 & 1 & 1 & 0 & 0 \\
\hline \multicolumn{8}{|l|}{ Cerrado } \\
\hline December & 1 & 0 & 0 & 0 & 0 & 0 & 0 \\
\hline \multirow[t]{2}{*}{ February } & 1 & 1 & 0 & 0 & 1 & 0 & 0 \\
\hline & $5 / 7$ & $3 / 7$ & $1 / 7$ & $1 / 7$ & $3 / 7$ & $0 / 7$ & $1 / 7$ \\
\hline Myotis nigricans $(\mathrm{N}=13)$ & Coleoptera & Lepidoptera & Diptera & Homoptera & Hymenoptera & Orthoptera & Hemiptera \\
\hline \multicolumn{8}{|l|}{ Gallery forest } \\
\hline June & 1 & 1 & 0 & 1 & 1 & 0 & 0 \\
\hline July & 1 & 1 & 1 & 1 & 0 & 0 & 0 \\
\hline August & 1 & 1 & 1 & 0 & 1 & 0 & 0 \\
\hline November & 1 & 0 & 0 & 1 & 1 & 1 & 1 \\
\hline December & 1 & 1 & 1 & 1 & 0 & 0 & 0 \\
\hline \multicolumn{8}{|l|}{ Cerrado } \\
\hline \multirow[t]{2}{*}{ February } & 1 & 0 & 0 & 0 & 1 & 0 & 0 \\
\hline & $6 / 13$ & $4 / 13$ & $3 / 13$ & $4 / 13$ & $4 / 13$ & $1 / 13$ & $1 / 13$ \\
\hline
\end{tabular}

Lepidoptera and Hymenoptera were found in four samples for E. furinalis and in seven for M. nigricans.

Homoptera, Diptera and Orthoptera were collected only in bats captured in gallery forest. Orthoptera fragments were found only in Myotis nigricans samples. An ant of genus Pheidole and a diptera of suborder Nematocera were also identified. In spite of the fact that $M$. nigricans (0.741) concentrated its feeding on a smaller number of prey items as seen by Shannon index $(E$. furinalis $=0.756)$, there is no statistical difference between this two values.

Therefore, there is $80 \%$ of overlap in the diet of these two species, value quite close to 1.0, indicating an almost complete overlap of food resources use. Both species are part of ecological interactions in their environment as secondary consumers and diet overlapping suggests that ecological segregation may be spatial or temporal. Myotis nigricans was collected during both seasons while Eptesicus furinalis occurred specially during the rainy season (November to February). The presence of both species can be directed affected by the annual life cycle of invertebrates, which is related to seasonal climate and resource availability. However, both species have similar diet without statistically significant differences between seasons $(\mathrm{Q}=0.673, \mathrm{p}<$ 0.563) due probably to the low number of samples.

Coleopterans, lepidopterans, homopterans, and hemipterans are among the major pests in farms (see OliveIRA 2005). Of all insect families, scarab beetles constituted the greatest proportion of the diet of E. furinalis and M.nigricans. This result is similar to Agosta (2002). He found that Coleoptera combined (i.e., including Scarabaeidae) constituted $>$ or $=30 \%$ of the diet of E. serotinus in any month. KurTa \& Whitaker (1998) say that Myotis diet is primarily of soft-bodied insects. MA et al. (2006) found that the 2nd most prominent food item for Myotis ricketti (Thomas, 1894). In China was beetles (Coleoptera), and the first was fish.

Data presented here is not enough to elucidate whether insectivorous bats are selective on certain groups of insects, or opportunistic, or specialized on particular insect groups only at certain times of the year (MA et al. 2006), but are enough to demonstrate the potential of bats as a biological control agent of pests in agricultural ecosystems.

Intensive studies of insectivorous bats should be encouraged in Brazil, especially in agricultural ecosystems, because they can be relevant when considering the integration of biodiversity and productive systems. It is known, for instance, that after natural disturbs the restoration of Lepidoptera community can be fast and complex, following succession stages of host-plants (Brown JR \& Freitas 1999). The same may be true for scarabeidae beetles too.

Although, in disturbs caused by man, most species are vanished and only resistant and well adapted persist and, lacking the biological population controls of their natural enemies, eliminated or reduced by agriculture, became important pests (SALVADORI 2000). 
Pests can grow to high population densities, retarding or inhibiting vegetal and animal succession, and consequentially leading to a poor system, that turns the restoration of the original state almost impossible (BRown JR \& FreITAs 1999), directly affecting agriculture due to insecticide use and the environment.

Although there is a lack of quantitative data to support it, bats potentially play a significant role in the biological control of economically harmful insects (Agosta 2002). Further study is needed on the potential impacts of bats on these economic pests in agricultural landscapes.

\section{ACKNOWLEDGEMENTS}

To the IBGE and Jardim Botânico de Brasilia for permission to work at their areas, and to two anonymous reviewers who helped to shape the paper. Financial support came from CNPq scholarship to first author.

\section{LITERATURE CITED}

Aв'SABER, A.1977. Domínios morfoclimáticos na América do Sul. Primeira aproximação. Geomorfologia 52: 1-22.

Agosta, S.J. 2002. Habitat use, diet, and roost selection by the big brown bat (Eptesicus fuscus) in North America: a case for conserving an abundant species. Mammal Review 32:179-198.

Aguiar, L.M.S. \& J. Marinho-Filho. 2004. Activity patterns of nine phyllostomid bat species in a fragment of the Atlantic Forest in southeastern Brazil. Revista Brasileira de Zoologia 21 (2): 385-390.

Aguirre L.F.; A. Herrel; R. van Damme \& E. Matthysen. 2003. The implications of food hardness to diet in bats. Functional Ecology 17: 201-212.

Brown, G.G.; A. Pasini; N.P. Benito; A.M. de Aquino \& M.E.F. CorREIA. 2001. Diversity and functional role of soil macrofauna communities in Brazilian no-tillage agroecosystems: a preliminary analysis. Londrina, Embrapa Soja, 20p.

Brown JR, K.S. \& A.V.L. Freitas. 1999. Reino Animalia: Ordem Lepidoptera, p. 225-243. In: C.R.F. BRandão; E.M. Cancello. (Eds). Biodiversidade do Estado de São Paulo, Brasil: síntese do conhecimento no final do século $\mathrm{XX}$, invertebrados terrestres. São Paulo, FAPESP, vol. 5.

Camargo, A.J.A. \& V.O. Becker. 1999. Saturniidae (Lepidoptera) from the Brazilian Cerrado: Composition and Biogeographic Relationships. Biotropica 31 (4): 696-705.

Clawson, R.L. \& D.R. Clark. 1989. Pesticide contamination of endangered gray bats and their food base in Boone County, Missouri, 1982. Bulletin of Environmental Contamination and Toxicology 42: 431-437.

Eiten, G. 1972. The cerrado vegetation of Brazil. The Botanical Review 38: 201-341.
Eiten, G. 1990. Vegetação, p 17-73. In: M.N. Pinto (Ed.). Cerrado: caracterização, ocupação e perspectiva. Brasília, Editora da Universidade de Brasília, 486p.

IBge. 2007. Estatística da Produção Agrícola. Instituto Brasileiro de Geografia e Estatística. Available in the World Wide Web at: http://www.ibge.gov.br/home/estatistica/indicadores/agropecuaria/lspa/default.shtm [Accessed in 14.IV.2007]

Krebs, C.J. 1998. Ecological methodology. Menlo Park, Benjamin/Cummings, $2^{\text {nd }}$ ed., 620p.

Kurta A. \& J.O. Whitaker Jr. 1998. Diet of the endangered Indiana bat (Myotis sodalis) on the northern edge of its range. American Midland Naturalist 140: 280-286.

Leelapaibul, W.; S. Bumrungsri \& A. Pattanawiboon. 2005. Diet of wrinkle-lipped freetailed bat (Tadarida plicata Buchannan, 1800) in central Thailand: insectivorous bats potentially act as biological pest control agents. Acta Chiropterologica 7 (1): 111-119.

MA, J.; J. Zhang; B. LiAnG; L. Zhang \& S. Zhang. 2006. Dietary Characteristics of Myotis ricketti in Beijing, North China. Journal of Mammalogy 87 (2): 339-344.

Oliveira, C.M. 2005. Aspectos bioecológicos do coró-das-hortaliças Aegopsis bolboceridus (Thomson) (Coleoptera: Melolonthidae) no Cerrado do Brasil Central. Planaltina, Embrapa Cerrados, Série Documentos 143, 28p.

Prado, D.E. \& P.E. Gibbs. 1993. Patterns of species distributions in the dry seasonal forests of South America. Annals of the Missouri Botanical Garden 80: 902-927.

Ratcliffe, B.C. 1991. The scarab beetles of Nebraska. Bulletin of the University of Nebraska State Museum 12: 1-333.

ReCOR 2007. Estação Climática da Reserva Biológica do IBGE. Available in the Wordl Wide Web at: http://www.recor.org.br/ Estacao/estacao.html [Accessed in 14.IV.2007]

SAlVAdori, J.R. 2000. Coró-do trigo. Passo Fundo, Embrapa Trigo, vol. 1, 56p.

Simmons, N.B. 2005. Order Chiroptera, p. 312-529. In: D.E. WILSON \& D.M. REEDER (Eds). Mammal species of the world: a taxonomic and geographic reference. Baltimore, Johns Hopkins University Press, $3^{\text {rd }}$ ed., 2000p.

TAshiro, H. 1990. Insecta: Coleoptera: Sacarabaeidae larvae, p. 1191-1209. In: D.L. Dindal (Ed.). Soil biology guide. New York, John Wiley and Sons, 1349p.

Whitaker Jr, J.O. 1995. Food of the big brown bat Eptesicus fuscus from maternity colonies in Indiana and Illinois. American Midland Naturalist 134: 346-360.

Whitaker JR, J.O.; C. NeEfus \& T.H. kUnz. 1996. Dietary Variation in the Mexican Free-Tailed Bat (Tadarida brasiliensis mexicana). Journal of Mammalogy 77 (3): 716-724.

ZAR, J.H. 1996. Biostatistical analysis. Upper Saddle River, Prentice Hall, $2^{\text {nd }}$ ed., 663p.

Received in 14.V.2007; accepted in 22.II.2008. 